\title{
The experience of OECD countries with public management reform and its relevance to Central and Eastern Europe
}

Citation for published version (APA):

van Mierlo, J. G. A. (1996). The experience of OECD countries with public management reform and its relevance to Central and Eastern Europe. METEOR, Maastricht University School of Business and Economics. METEOR Research Memorandum No. 038 https://doi.org/10.26481/umamet.1996038

Document status and date:

Published: 01/01/1996

DOI:

10.26481/umamet.1996038

Document Version:

Publisher's PDF, also known as Version of record

Please check the document version of this publication:

- A submitted manuscript is the version of the article upon submission and before peer-review. There can be important differences between the submitted version and the official published version of record.

People interested in the research are advised to contact the author for the final version of the publication, or visit the DOI to the publisher's website.

- The final author version and the galley proof are versions of the publication after peer review.

- The final published version features the final layout of the paper including the volume, issue and page numbers.

Link to publication

\footnotetext{
General rights rights.

- You may freely distribute the URL identifying the publication in the public portal. please follow below link for the End User Agreement:

www.umlib.nl/taverne-license

Take down policy

If you believe that this document breaches copyright please contact us at:

repository@maastrichtuniversity.nl

providing details and we will investigate your claim.
}

Copyright and moral rights for the publications made accessible in the public portal are retained by the authors and/or other copyright owners and it is a condition of accessing publications that users recognise and abide by the legal requirements associated with these

- Users may download and print one copy of any publication from the public portal for the purpose of private study or research.

- You may not further distribute the material or use it for any profit-making activity or commercial gain

If the publication is distributed under the terms of Article $25 \mathrm{fa}$ of the Dutch Copyright Act, indicated by the "Taverne" license above, 


\title{
THE EXPERIENCE OF OECD COUNTRIES WITH PUBLIC MANAGEMENT REFORM AND ITS RELEVANCE TO CENTRAL AND EASTERN EUROPE
}

To Be Published as Chapter 13 in David Coombes and Tony Verheyen (eds.), 'Can Public Management Innovations as Applied in Western Europe and Other OECD Countries be Applied Successfully in Central and Eastern Europe',

Report for the European Commission, Brussels, University of Limerick, November 1996 ACE/Phare Programme 1994, Research Grant 94-0175-R, (also to be published by Edward Elgar Publishers, Aldershot UK, 1997)

\author{
J.G.A. van Mierlo \\ Associate Professor of Public Economics \\ Faculty of Economics and Business Administration \\ University of Maastricht \\ P.O. Box 616 \\ 6200 MD Maastricht \\ The Netherlands \\ Tel ++31 43 3883641/3636 \\ Telefax ++31433258440 \\ E-mail h.vanmierlo@algec.unimaas.nl
}

November 1996 


\title{
Summary \\ The Experience of OECD Countries with Public Management Reform and its Relevance to Central and Eastern Europe
}

\author{
J.G.A. van Mierlo, University of Maastricht
}

In this paper, the experience of OECD countries with public management reform, as has been attempted since the nineteen seventies until now, is discussed. In particular we focus on the lessons which can be drawn from public management reform attempts in English speaking countries on the one hand (the 'Anglo-saxon tradition' in public management reform), represented by the United Kingdom, Ireland, Australia and New Zealand, and in countries on the European continent (the 'continental tradition' in public management reform), represented by the Netherlands and France. The relevance of the experience of these Western countries with public management reform to countries in Central and Eastern Europe, such as Bulgaria, Hungary and Slovakia, will be pointed out. For this purpose, the results and conclusions of the various country chapters in the report will be employed. A critical examination of this relevance is necessary to formulate an answer to the central question of this ACE Phare research project: can public management innovations as applied in Western Europe and in other OECD countries be applied successfully in Central and Eastern Europe? 


\section{Contents}

Summary

1. Introduction

2. Problems in public management reform

2.1 Defining the real problem

2.1.1 Governments and markets are institutional arrangements 2

2.1.2 Bureaucracy is the problem

2.2 Defining the right solution(s)

2.2.1 More political control

2.2.2 Radical privatisation

2.2.3 Competition in the public sector

2.3 Coping with format problems

3. Lessons to be learned

Lesson 1: An instrumental perspective

Lesson 2: The problem of bureaucracy

Lesson 3: An open process approach

Lesson 4: Horizontal policy networks

Lesson 5: Organisational variety

Lesson 6: Policy analysis and performance measurement

Lesson 7: Determinants of success and failure

Lesson 8: Organisational learning capacities

Lesson 9: Ecological analysis

Lesson 10: Organisational culture

Lesson 11: Institution building

4. Conclusion

References 


\section{Introduction}

In this chapter the experience of OECD countries with public management reform, as has been attempted since the nineteen seventies until now, is discussed. In particular we focus on the lessons which can be drawn from public management reform attempts in English speaking countries on the one hand (the 'Anglo-saxon tradition' in public management reform), represented by the United Kingdom, Ireland, Australia and New Zealand, and in countries on the European continent (the 'continental tradition' in public management reform), represented by the Netherlands and France. The relevance of the experience of these Western countries with public management reform to countries in Central and Eastern Europe, such as Bulgaria, Hungary and Slovakia, will be pointed out. For this purpose the results and conclusions of the various country chapters in this report will be employed. A critical examination of this relevance is necessary to formulate an answer to the central question of this research project: can public management innovations as applied in Western Europe and in other OECD countries be applied successfully in Central and Eastern Europe?

The structure of this chapter is as follows. After this brief introduction a critical assessment of problems in public management reform, as shown by various public management reform attempts, will be presented in section 2 . In section 3 the lessons to be learned from various experiences with public management reform are discussed. In principle, these lessons are relevant for attempts to public management reform in Central and Eastern Europe. However, their relevance for Western European countries will also be apparent. Why should only others learn from mistakes you made yourself? The theory of organisational learning teaches us that organisations can learn at least as much from their own mistakes as from mistakes made by other (competing) organisations. Some final conclusions will be formulated in the closing section 4 of this chapter.

\section{Problems in public management reform}

An investigation of the various country chapters in this report results in the following list of problems of public management reform:

-problems in defining the real problem of public management (the causes);

-problems in formulating the right solutions for the stated problems (the remedies);

-format problems in the public management reform programmes (referring to problems of formulation, of implementation, and of feedback and evaluation).

\subsection{Defining the real problem}

The first and most important problem lies in the definition of the central object of public management reform. What is actually the problem of public administration at which public management reform is aimed? What is the central problem for which public management reform is supposed to provide solutions? The specifications of the 'problem definition' or 'problem statement' determine largely the contents of the proposed solutions, as well as the outcome of these solutions in terms of success and failure. The experience of OECD countries with public management reform however shows, that the very problem definition itself meets several difficulties.

In the first place, the political (and scientific) debate on public management reform many times is conducted in concepts and formulations testifying blind ideology for or against the government or the market. Government and market are considered as institutions with intrinsic 
values and hence as policy-objectives as such, to be pursued by reform policies. Either government is approached as an institutional arrangement which always works better and the market is condemned as an inferior alternative, or the market is approached as a perfect institutional arrangement and government is accused of working always worse. The first approach is applied by 'etatists', the second by 'market-fetishists'.

\subsubsection{Governments and markets are institutional arrangements}

However, one might consider both institutional arrangements as instruments for public service delivery, which may realise various policy-aims, varying from allocative efficiency, via distributive justice (equity), to consumer sovereignty (democracy), and so on. Governments and markets are no ends in themselves, but are specific means to realise certain ends. Hence, they are institutions which have an instrumental value. Governments and markets are not good or bad per se, but have to be judged by their contribution to specific policy-objectives. Does the market serve better the aim of allocative efficiency, or the government? Does the government serve better the aim of distributive justice, or the market? Does the market serve better the aim of consumer sovereignty, or the government?

There are no general, unique and everlasting answers to these questions. Sometimes, government works better, sometimes the market does. Sometimes efficiency is promoted better by the market, sometimes by government; sometimes equity is promoted better by government, sometimes by the market. Sometimes the postulate of consumer sovereignty is respected more by the market, sometimes more by government. The answer varies with the goods and services at stake (depending on their technical characteristics in terms of (non-) excludability and (non-) rivalness of consumption; see Savas, 1987), with technological developments at the supply-side of service delivery systems, and with taste: the consumers preferences at the demand-side of service delivery systems.

Governments and markets are means to realise social and political goals, they are no ends as such. In addition, they are no perfect means for all ends. As one author (Wolf, 1988) put it: governments and markets are a choice between imperfect alternatives. There is not only such a thing as market failure, but there is also the problem of government failure (Wolf, 1979). In a scientific comparison between both imperfect alternatives, the contribution of each institutional arrangement to various policy objectives has to be determined and evaluated. This implies that both alternatives may be compared with each other either on the level of the 'ideal-type': the ideal models of government and market, or on the level of the 'real-type': the reality of the muddles.

Cross-comparison over different levels, confronting the model of the one species with the muddle of the other, implies a serious methodological fallacy, because than the model will always win from the muddle (see Van den Doel, 1979: p. 153). In conclusion: with regard to the problem of choosing between imperfect alternatives of government versus market, blind ideology for or against one or the other does not bring us further. Both institutions have to be investigated on their economic effects on collective welfare. A choice between the two has to be made on basis of a political evaluation of these effects (see Barry and Rae, 1975).

\subsubsection{Bureaucracy is the problem}

Secondly, the real problem lies not in the one institution or the other, but in the tendency in both institutional arrangements for 'bureaucratization' and 'bureaucratism' as a pathological deviation of the neutral organisational concept of 'bureaucracy'. Originally, the bureaucratic organisation 
has been constructed as a technical device for serving certain problems of large organisations (see e.g. Wilson, 1887; Weber, 1922/1964). Bureaucracy may be regarded as the ideal type of a perfect hierarchy of trained professionals. The real bureaucrat is not engaged in politics but administers, i.e. he administers impartially. The bureaucrat will fulfil his duties 'sine ira et studio' (without passion and without partisanship). So he does not do what the politician always has to do, that is, fight. Taking sides, battle, passion - 'ira et studium'! - these are the essence of politics. The bureaucrat's professional honour lies in his ability at all times to carry out his superior's orders, conscientiously and scrupulously, irrespective of whether his objections to certain policies have been followed or ignored. Politics is decision-making about values, administration is implementation of these political decisions by the bureaucracy. Bureaucracy is not about values, but about technics.

Yet, this classical governmental view of bureaucracy must be discarded from an economic viewpoint. The public choice approach has contributed to what nowadays has become the 'economic theory of bureaucracy' (e.g., Williamson, 1964; Niskanen, 1971). In the well-known Niskanen-model of bureaucracy, the aims of bureaucrats are not derived from and neither subordinated to the aims of politicians. Bureaucratic preferences are independent from political preferences. Bureaucrats are motivated by utility-maximisation. Utility-maximisation is served by 'budget-maximisation' or 'maximisation of the size of the bureau'. Niskanen assumed that the objective functions of politicians and bureaucrats differ and this assumption forms the essence of his model. The difference means that the politicians and department heads do not strive to achieve the same ratio between the output of the bureau and real costs. For politicians a public programme is most attractive when output is expanded to the point of maximum difference between its total benefits and its total costs. The utility of the leading bureaucrats is relatively more affected by the benefits than by the costs. For the leading bureaucrats the benefits of a public programme consist of a rise in salary, an increase in power and prestige, or satisfaction in their social usefulness. However the cost of a public programme is borne by the voter, in the form of taxation, and by consequence by the politician in the form of a loss of votes. To a certain extent, the bureaucrats are indifferent to the sacrifices politicians have to make to provide funds.

Van den Doel (1979: p. $131 \mathrm{ff}$.) explains, that the political optimum is determined by the output the politicians demand. The bureaucratic optimum is determined by the output of leading bureaucrats. In the simple Niskanen-model the output desired by the bureaucrats is twice as large as that desired by the politicians. Niskanen characterised the power relations between politicians and bureaucrats as a bilateral monopoly. In that case, the outcome of the negotiations between both cannot be determined theoretically. In practice, in his opinion, the bureaucrats generally succeed in getting their own way. Niskanen explains this by saying that politicians are not aware of the real cost function. They know only one point in the cost function, the amount spent on costs at that moment. If this point coincides with the bureaucratic optimum, then every managerial audit will show that the costs do not include any wastage. After all, departments cannot reach the bureaucratic optimum by wasting money. Extravagance would force the cost function upwards and this would lead the politicians to propose cutting down on the output of a variety of public programmes. From the bureaucratic point of view the ideal situation can only be attained by extending the production of public goods beyond the point the politicians find desirable. If there is any inefficiency in bureaucracy, it must be sought not in the cost of each public good but in the level of output of these goods.

Bureaucracy is characterised by a hierarchy of bureaucrats, who, though they receive orders from elected representatives, have a certain range of choice in the extent to which they carry out these orders. They use this range of choice to exploit fully the preparedness of voters and 
politicians to accept a certain budget, if necessary, so that the output of the services provided by a bureaucracy in most cases exceeds that which would have been provided by the preferences of the voters and the politicians. The fact that the bureaucracy dos not work at an optimum can ultimately be explained by two factors: on the one hand the aims of leading bureaucrats, on the other, the possibility of realising these aims which results from the monopoly position of a department. These then are the sources of bureaucratic power: hierarchy in the internal organisation of bureaucracy, resulting in the dominance of the aims of the leading bureaucrats, and monopoly in the external organisation of bureaucracy, resulting in exploitation of the politicians and the voters. If remedies are to be found, they must be sought in the removal of these causes.

\subsection{Defining the right solution(s)}

In most public management reform attempts, formulating the right solutions for the stated problems (the remedies) appears to meet serious difficulties. If bureaucracy is the real problem, the central question of public management reform becomes: what can be done against bureaucracy, becoming bureaucratism through processes of bureaucratization? Two yet classical answers have been applied in public management reform in the Western World thus far. The first answer is: more 'political control' of the bureaucracy. The second answer is: 'radical privatisation', thus eliminating bureaucracy in the public sector.

\subsubsection{More political control}

More political control is the first answer to bureaucracy. This solution targets at the one main problem of bureaucracy, which is the monopoly position each department has. This monopoly position makes it possible for bureaucrats to make politicians choose between all or nothing, thus forcing them to buy their services at a loss. Political reformers, faced with the power of bureaucracy, are always trying to solve this problem by making proposals to sharpen the 'political' or 'external control' of the bureaucracy.

Many proposals have been formulated, many attempts to implement these proposals have been made. Van den Doel (1979: p. 141) presents the following measures under this label: the organisation of parliament must be improved, members of parliament should concern themselves more with their departments, ministers should give more guidance to their ministries, an ombudsman should be appointed, a system of continuous and scrupulous policy analysis should be established, and so on. He emphasizes, however, the limited effectiveness of these attempts to strengthen the external control on government bureaucracy.

The proposed measures of external control of bureaucracy have been part of a long ongoing debate in the Netherlands on 'constitutional, political and administrative renewal' of the Dutch political system. This debate already started in the Netherlands with the end of the era of 'Pillarisation' in the nineteen sixties, as we have seen in Chapter 9 of this report. The debate continues until nowadays, inspired many public management reform attempts and yet has yielded limited success. In the United Kingdom, the debate on public management reform resulted in the movement of so-called Modern Public Management (MPM, see Chapter 8 in this report for its applications in the United Kingdom), of which the theoretical foundations and principles have been discussed in Chapter 3. Modern Public Management builds further on the managerial tradition in business administration, as founded by the contributions of Fayol and Taylor. Modern Public Management advocates the application of classical managerial principles and instruments in the 
organisation of public administration, such as a clear analytical distinction between politics and administration, resulting in a practical and physical separation between the process of political decision-making (by Cabinet, Ministries and Parliament) and the administrative implementation of these decisions (concentrated in Agencies, placed at a certain distance from the Ministries).

These and other measures as proposed by the MPM-movement emphasize not external control on bureaucracy, but 'internal control': separation between politics and administration implies at the same time a stronger control of the bureaucracy by the political authorities. Van den Doel (1979: p. $149 \mathrm{ff}$.) argues that internal control of politicians is confronted with the same limitation of scope as external control, because both forms of political control do not change anything in the foundations of bureaucratic power. Many of the proposals of the MPM-movement have been applied in public management reform in the UK by various conservatives governments under Thatcher and Mayor. In Chapter 8 it is argued, that these attempts in the UK have booked mixed success. Moreover, many of them can be considered to have caused new public management problems, e.g., problems of administrative accountability and parliamentary controllability.

The conclusion is inevitable: efforts to improve internal as well as external control of the bureaucracy by politics have more less failed thus far and have resulted in much less success than modern theories of public administration (e.g., MPM) have predicted. All in all, these efforts can be characterised as attempts to fight bureaucracy with more bureaucracy, because they all rely on bureaucratic devices to control bureaucracy. And as we all know: the Devil cannot be beaten by Beelzebub.

\subsubsection{Radical privatisation}

Another answer to bureaucracy has been: 'radical privatisation'. Radical privatisation implies the transfer of public activities from the public budget sector to the private market sector, and hence the transfer of public organisations employing these public activities, the government bureaus, to the private market sector. Privatisation has been popular in the nineteen eighties in the United States of America (see Savas, 1987) as well as in the United Kingdom. Mass privatisation of public activities and of public organisations has been undertaken by the Reagan-administrations and the Thatcher-governments. However, the 'euphoria' among politicians and in public opinion about privatisation has changed in the nineteen nineties, not only in the USA and in the UK, but also on the European continent, as has been argued in the various country chapters in this report. Massive privatisation in the USA and in UK has not brought the promised results in a convincing manner. In the Netherlands and in France, privatisation has been undertaken with much more caution and with much more recognition of the problems and disadvantages of privatisation.

Privatisation is not a panacea for the problems of bureaucracy in the public sector. it seems that by privatisation the problem of bureaucracy is not really solved, but is simply defined away. First of all, there has been an argument in the past for defining a specific activity as a public activity and for making a public organisation responsible for undertaking this activity. This argument may be derived from the theory and practice of 'market failure'. When markets fail, there may be a case for public provision of goods and services. However, when in turn there rises such a problem as 'government failure', this does not automatically and inevitably leads to the conclusion that the market mechanism will work better. There is no logical reason why the former market failure will have disappeared with the transfer of the originally market activity to the public sector. The previous market failure may still be present and even new market failures may have risen. In other words: governments and markets are imperfect alternatives to choose between, and in case by case a comparison of the various advantages (benefits) and disadvantages (costs) of both institutional 
arrangements has to be made when considering the transfer of certain activities and responsibilities from one sector to the other (privatisation) or the other way around (so-called 'publicisation'). The privatisation of certain public utilities, of health care provisions, and of housing and education services has given substantial evidence for our warning to be cautious with the potential dangers of neglecting old or new market failures.

In addition, privatisation does not solve automatically the bureaucracy problem. Without accompanying measures, the transfer of the public organisation to the private sector implies also the transfer of the problem of the former government bureaucracy to the private sector. Public bureaucracy becomes private bureaucracy, but is still bureaucracy. We have concluded above, that the second problem and source of bureaucratic power is the monopoly position of the bureau in the provision of public goods. Simple privatisation of the monopoly bureau to the private sector does not change the monopoly position of the bureau. Mere privatisation implies that the public government monopoly is substituted by a private market monopoly. In that case, the situation may be considered to have worsened: a public monopoly is at least in theory and in principle under control of political authorities, elected by citizens to protect their consumer interests against producer exploitation by public monopolies, e.g. public utilities. A private market monopoly lacks such political arrangements for consumer protection. Ultimately, ceteris paribus citizens/consumers will be worse of with market monopolies as compared with public monopolies. If the privatized firm operates within a monopolistic market and also aims at maximising profits (as every private firm in a market system does), an industrial-economic analysis shows that we go from one extreme to another extreme: the too great expansion of services by a government bureaucracy is now exchanged for a too great contraction by a private monopoly. Only under the condition that the monopolistic firm does not strive after maximum profits but after a maximum output instead, a social welfare optimum does become possible. However, there is no guarantee that a monopolistic firm after privatisation will strive for maximum output instead of for maximum profit, for example because maximising output results in private economic losses at the cost of shareholders profits.

Consequently, privatisation of a public monopoly should be accompanied by putting in simultaneously competition, in order to prevent the public monopoly in becoming a private monopoly. This can be done by splitting up the previous monopolistic firm into various new competitive firms. However, this split up may also involve the loss of substantial scale economies which can only be realised by one monopolistic firm and not be various smaller competing firms in the same branch of industry. Precisely this phenomenon of 'scale economies' is a well-known category of market failure and has been applied as an argument for making the private monopoly in question a public monopoly. This has been the case with public utilities in Western Europe. Thus, a welfare economic analysis proves that privatisation makes competition necessary and that putting in competition is a prerequisite for privatisation. But at the same time the analysis shows that competition may not be possible or may not be efficient. Again, economics appears to be a dismal science!

This private monopoly-problem after privatisation has occurred in the early eighties in the Netherlands in a most extreme form (see Chapter 9 for the details). Privatisation of the pilot-system was undertaken without taking into consideration the necessity of putting some form of competition into this branch. After privatisation, the pilots took a private monopoly position instead of a public monopoly position. On the other hand, government regulations stayed intact: every ship coming into a Dutch harbour has the obligation to let itself be guided by a now privatized pilot. Pilot clients were guaranteed by government regulation. Pilots interests and not consumer services were protected by this government regulation, because pilots were completely free in setting their prices. This is a very comfortable position for a monopolistic firm: clients were 
forced to make use of their services and they had to pay the prices charged by the service providers. The voice-option was not longer available for clients (political authorities were no longer responsible and accountable for the prices, the quantities and the qualities of the services) and the exit-option (the freedom to buy services from other providers, delivering higher quantities and better qualities against lower charges) was denied to them. Indeed, the Dutch pilots increased their charges and decreased the amounts and the quality of their services; the could do so because their clients had no choice at all. In the end, everybody except the pilots was worse off: producers seized a large part of the consumer surplus, but the gain of the producers was smaller than the loss of the consumers. Total collective welfare has not increased as a result of this specific privatisation but has diminished. This is the so-called 'dead weight loss' of monopoly. This way of privatisation has become a famous case in the Netherlands. It is a convincing example of what can go wrong with privatisation if one looses sight of the practical lessons taught by solid and standard welfare economic theory.

Making use of bureaucratic devices (more internal control as well as more external control) does not work in fighting bureaucracy. Neither does radical privatisation. Neither alternative tackles the sources of bureaucratic power: hierarchy and monopoly. Political control reinforces the problem of bureaucracy, privatisation shifts the bureaucracy problem from the public sector to the private sector. In both ways there is a great danger that the problem has not solved, but even has grown bigger.

\subsubsection{Competition in the public sector}

A more promising solution should tackle the heart of the problem: the foundations of bureaucratic power, i.e. internal hierarchy and external monopoly. These problems are tackled by putting in 'competition into the public sector', i.e. stimulating 'competition between bureaucrats'. This revolutionary idea already has been introduced by Van den Doel (1979) in the formulation of his model of 'self-management of civil servants', in analogy of the economic model of 'labour selfmanagement in the private sector' developed by Vanek (1970; 1975). Van den Doel (1979: p. 169 ff.) starts his argument with stating that departments formulating programmes, instead of being hierarchically structured, ought to be of a collegiate, self-directing type. He defines the characteristics of self-management by civil servants as follows:

1. all civil servants in a department are equal from an organisational point of view in so far as they choose representatives on a majority vote, who decide on a department's policy and on the appointment of departmental heads;

2. the department is financed exclusively by a budget authorised by the politicians;

3. the politicians negotiate with the departmental representatives about the tasks to be performed for the budget to be provided, and they secure the coordination between the departments;

4. no single department has the exclusive right to provide specific public goods.

Van den Doel applies a mathematical model as well as a graphical model to prove, that his concept of self-management by civil servants results in a specific output-optimum. Under the assumption that the members of the worker's collective of the self-managed bureau strive after their own interests, confining themselves largely to matters connected with their income, it is not profit (or output) as such which is maximized, but the profit (or output) per worker. Assuming further that a civil servant is not interested in increasing fixed capital costs, civil servants no longer strive to maximise the total budget (or total output), but maximize the (for their remuneration) available budget per civil servant. After the establishment of self-management, the civil servants will go from one extreme to another. The excessive increase in the output of the hierarchical 
bureaucracy is succeeded by an excessive contraction in the output under self-management. A consequence of the implied aim is that in the short run the present service will, in a situation of self-management, exploit their monopoly to provide relevant services by preventing new colleagues from joining the civil service corps as is normal in professions, e.g. medicine, notary, and lawyers. For this reason, the fourth characteristic of self-management by civil servants is formulated, that no single department should have the exclusive right to provide specific public goods. This means that other departments will have free entry or that existing departments can take over the tasks of other departments on condition that government finances these initiatives. This condition allows a government to pursue a policy of entry which makes it possible to avoid waste from duplication.

Under conditions of perfect competition in the administration, politicians are able to confine their executive task to comparing the various plans drawn up by an number of competing departments and choosing the best. This can be considered as a specific form of 'contracting out', however not to firms in the private sector but to competing bureaus in the public sector! In practice, competition will never be perfect because it is difficult so set up a new bureaucratic department (because of the phenomenon of 'sunk costs'). Yet the possibility that a new department can be set up will work preventively (cf. the new concept of 'contestability' in market theory). For fear of a potential competitor the existing departments will be more conducive to the wishes of the politicians. The market for administrative services will no longer be characterised by a bilateral monopoly between the politicians and the bureaucrats, but it will get an asymmetrical structure because the one group of politicians will be able to negotiate with competing departments. In the second characteristic of self-management it is formulated that in such a market structure the politicians will be the sole buyers (monopsony) which will give them a strong bargaining position.

Van den Doel himself emphasizes the heuristic significance of his model. Collective welfare can be increased by replacing the traditional hierarchical structure in an administration wholly or in part by an 'entente' organisation such as sometimes can be found in Western hospitals and schools. Self-management by civil servants is one way to stimulate collegiate management and administrative competition, which also can coincide with the pursuit by the public of optimum collective welfare.

Almost twenty years later, the model of self-management by civil servants does not appear as utopian as it was originally. The practice of public management reform in the Netherlands, as treated in Chapter 9 of this report, involves specific varieties of 'contract-management' and 'selfmanagement', which resemble logically one or more of the four characteristics of the original model of self-management by civil servants. In addition, the concept of 'public entrepreneurship' for public organisations is developed by Osborne and Gaebler (1992). Attempts to introduce certain elements of public entrepreneurship into public organisations, thus bringing into practice the idea of 'reinventing government', are undertaken by the Clinton-administration in the USA. The concept of public entrepreneurship is discussed in Chapter 3 of this report. Several of the ten principles of public entrepreneurship are related to the model of self-management by civil-servants or are compatible with this model. Public entrepreneurship implies the introduction of competitive devices into the public sector and into public service delivery systems. Putting competition into the public sector, using elements of the model of self-management by civil servants and of the concept of public entrepreneurship, may provide an escape from the tragic dilemma between 'fighting bureaucracy with more bureaucracy' and 'defining bureaucracy away by radical privatisation'. Some countries in Western Europe have practised elements of this third solution in their efforts for public management reform. Perhaps they could have done more with the concept of 'competition in the public sector' (see also Van Mierlo, 1985). This concept might also be useful for public management reform in Central and Eastern Europe, as we will discuss below. 


\subsection{Coping with format problems}

Finally, not only the contents of the solutions to public management problems, as formulated in public management reform programmes, suffers in many cases from analytical difficulties. Many of these solutions also have so-called 'format problems', as has been shown in the various country studies in this report. Format problems arise when policy programmes do not fit some analytical requirements which can be derived from the policy-sciences. Many programmes for public management reform in Western European countries show problems with regard to their policy objectives. The formulation of policy objectives is unclear; they are contradictory between programmes and even within one and the same programme; they are changing over time (the problem of shifting policy objectives); and they are decided upon by technocratic methods of decision-making (the bureaucrats, their advisers and the academic reform experts, themselves) instead of by democratic methods of political decision-making (the politicians, the interest groups, public opinion and the mass media, the citizens as voters and as policy-consumers).

Secondly, there are several format problems with respect to the policy instruments contained in the policy programmes of public management reform. In many occasions their relation with the formulated remains unclear (the problem of the policy-theory, translating 'cause-effect relations' into 'means-goals relations'); policy instruments contradict each other and are inconsistent; the occurrence of negative-side effects is not investigated or neglected; and again the choice of policy instruments for public management reform is considered to be a matter of technics instead of democratic political decision-making.

Thirdly, implementation problems are neglected or under-estimated in many public management reform programmes. When reform programmes come into execution, coordination and accountability problems arise. Who (which official, which institution) has to do what and who is responsible for what? Systematic attention for success and failure of public management reform programmes is lacking or is insufficient: the effects of public management reform are not measured, success or failure is not established, determinants of success and failure are not investigated. Finally, there is no systematic attention for favourable and unfavourable process conditions for public management reform (technical conditions of feasibility, democratic conditions of legitimacy).

Fourthly and lastly, problems in the feedback mechanisms and of evaluation and correction of policy measures are neglected too often. Many times, feedback mechanisms are not built in the reform programmes or they are neglected and remain unused. During the implementation process, systematic evaluation of the effects of reform measures is lacking or insufficient. Attention for processes of and capacities for 'organisational learning' is absent or insufficient. Finally, the problem of 'organisational fit' is neglected. Serious attention for the political, economic and social environment of organisations is necessary, because much of the success and failure of change management in and of (public) organisations depends on the (dynamic) compatibility between organisations and the environment in which they operate. Workable and useable knowledge is produced by academic disciplines such as the 'economics of organisation ecology' and the sociological contingency theory', but in many public management reform attempts of Western countries these insights are overlooked.

\section{Lessons to be learned}


What is the relevance of the experience with public management reform in OECD and other countries for countries in Central and Eastern Europe? Various lessons may be learned from successes but in particular from failures in public management reform in the Western world. Eleven lessons to be learned by Central and Eastern European countries are presented in this section.

\section{Lesson 1: An instrumental perspective}

Ideological standpoints about governments versus markets should be avoided. Governments and markets are no ends as such, but have to be considered as means to realise other sends, viz. economic ends determined democratically by society, such as efficiency in allocation of scarce resources, equity in distribution, democracy and legitimacy of decision-making about allocation and distribution, and so on. Governments and markets are institutional arrangements to provide goods and services, both of which serve some policy objectives better than others. A pragmatic and instrumental approach should be preferred. In such a pragmatic approach the so-called 'trade off' between conflicting policy objectives has to be considered, e.g. the trade off between efficiency and equity (see Okun, 1975).

Furthermore, complex institutional arrangements of public service delivery systems, each meeting different combinations of policy objectives, will be discovered applying a more pragmatic approach to governments various markets. Complicated questions require complicated answers. There are no easy solutions to complicated questions, such as: which institutional arrangement serves the maximisation of the policy objective of allocative efficiency better in the provision of good x, y, and z, and so on? The economic system (e.g. the market) is not and end it itself, neither as the political system (e.g. representative democracy) is. The quest for public management reform in Western Europe as well as in Central and Eastern Europe should be pursued from this instrumental perspective on the politico-economic system.

\section{Lesson 2: The problem of bureaucracy}

In an instrumental approach to the government versus market problem, the problem statement becomes crucial. What is the central problem for which public management reform attempts to produce a solution. There is serious evidence that bureaucracy, bureaucratism and bureaucratization is the central problem of modern government and administration. Two classical solutions for the bureaucracy problem have been applied in public management reform in the Western world: more political control of the bureaucracy and radical privatisation.

The first solution, strengthened political control (be it internal or external control), implies that bureaucratic means are introduced to fight bureaucracy. Bureaucracy is attacked with even more bureaucracy, as a result of which the bureaucracy problem is not solved but even will be worse. The second solution does not work without parallel and simultaneous competition. A market monopoly is even worse for collective welfare than a government monopoly. In addition, there is always the danger of market failure. Instead, 'competition in the public sector' seems more promising with regard to breaking down the foundations of bureaucratic power. The model of 'selfmanagement by civil servants' as well as the concept of 'public entrepreneurship' may be useful not only for improving the effectiveness of public management reform in Western Europe, but also for countries facing the same problems of public management reform in Central and Eastern Europe. 
Attempts to public management reform should not be undertaken from a so-called 'closed programme approach' of grand designs and technocratic solutions, i.e. programmes in which a priori policy objectives are set and corresponding policy measures are selected, without any possibility for changing means and ends during the implementation processes. During the implementation of every policy programme, circumstances always change. At the supply side, technological development does not stand still. Technological solutions unthinkable of today or considered unworkable, will be available tomorrow. At the demand side, consumer's tastes change continuously. Citizens' preferences are not stable but are developing constantly over time. Solutions unfeasible because unacceptable today will become feasible and acceptable tomorrow.

Instead, an 'open process approach', allowing for small steps within narrow margins of change and determined by the limits of democratic acceptance of such change, is preferable. In such an open process approach, policy changes are easily to be accomplished if judged to be necessary. In such an open process approach, policy programmes can easily be adapted to changing supply and demand conditions. This implies also a completely different role of government. The government does not determine or prescribe the particular contents and outcomes of the process, but is responsible for the process itself, i.e., the process conditions. In the open process approach, government operates as the 'process architect'. This statement in particular holds truth in respect with public management reform in West and in East, by which the constitutional framework for the politico-economic system is decided. Government should take responsibility for the process of public management reform, not for the contents and the outcomes.

\section{Lesson 4: Horizontal policy networks}

Vertical and hierarchical bureaucratic devices with their inherent top-down decision-making structures are no longer the solution and ultimate objective of public management reform. In modern society, emancipated and democratic citizens no longer will accept the dominance of bureaucratic organisations in their systems of public and private service delivery systems. Modern citizens do not accept to be treated as mere objects of public services. They also want to be considered as autonomous subjects of these systems. Nowadays, citizens are no longer mere dependent clients and passive consumers, but also sovereign masters and producers of public goods and services at the same time (the issue of 'empowerment').

Horizontal and democratically organized policy networks with bottom-up decision-making structures will work better in fulfilling citizens' demands for public goods and services. Governments have no longer an monopoly in the provision of these goods and services, but will have to cooperate with various nongovernmental organisations (NGO's) and even private firms. Community based services and empowerment of clients/citizens are the modern principles of public organisation. As the transition to a mixed, market-oriented economy makes progress in Central and Eastern Europe, the demand for these modern organisation principles in the public sector will grow.

\section{Lesson 5: Organisational variety}

There are no eternal solutions for problems of public management, no 'uniform blueprints' and neither 'draw table answers'. Public management solutions are not invented in technical laboratories, because there is no such a thing as a merely technical solution for problems which are in 
principle political. Public management and public administration involve political values as well as technical values. The political components of the problem of public management, and hence of public management reform, dominate over the technical components.

Modern society in West and in East is characterized by all types of structural and cultural differences. Hence, 'organisational variety' and 'social, political and economic experiments' are the modern keywords of public management. Public management solutions having proved to work in the Netherlands, not necessarily will work also in France, or for that matter in Bulgaria or in Hungary. Public management reforms having proved to be successful in Paris or London, or Sofia or Bratislava, will not necessarily be equally successful in Lutjebroek (a small village in the Netherlands), Vesprem (Hungary), Luki (Bulgaria) or Banska Bystrica (Slovakia). Public management solutions in central government not necessarily will work also in local government, public management solutions in government not necessarily will work in health care or in education. Modern public management reform should allow for more organisational variety and for reform experiments. Citizens becoming increasingly independent sovereigns in the private sector, want to be treated as such also in the public sector. There is no 'bifurcated man' left in the near future.

Lesson 6: Policy analysis and performance measurement

Modern techniques of policy analysis, such as 'systematically collected policy information' and 'performance measurement' should become common practice in public management reform in West as well as in East. Attempts to public management reform should be evaluated continuously on the degree of their success or failure. Only systematic evaluation against democratically decided standards will give evidence about the outcome of public management reform.

In the end, the most important question of public management reform is: does it work better from a democratic viewpoint, i.e. from the viewpoint of collective welfare as considered by the citizens themselves. The question then is: whose preferences will count, policy makers' preferences or citizens' preferences? The liberal-democratic postulate 'Ultimately, each individual can only speak for himself' is in particular valid in issues of public management reform, because in a democratic society the government belongs to the people, not to the politicians and neither to the bureaucrats. Ultimately, the object of public management reform is to give government back to the people.

\section{Lesson 7: Determinants of success and failure}

In the same line with the previous lesson lies the next lesson: a 'systematic analysis of the determinants of success and failure' of public management reform is preferable. Does public management reform produce the claimed results and if so, why, and, even more important, if not or if not sufficiently, why? If we know whether and why, under which conditions and to what extent, a specific public management reform is a success or a failure, the probability of success of future attempts to public management reform may be improved. If this information is not (made) available, we do not know what we are heading for. This is the more true where resources are scarce and public management reform competes with other economic activities for these scarce resources, as is the case in Central and Eastern Europe. 


\section{Lesson 8: Organisational learning capacities}

More attention should be paid to and more emphasis should be put on improving the 'learning capacities' of (public) organisations. People do make mistakes and they may learn from the mistakes they make themselves and from those others make. Organisations consists of people and organisations have learning capacities too. This is true for all organisations, be in the private sector or be it in the public sector. Public management reform should allow for mistakes made by individual people, public managers, as well as by public organisations.

Learning capacities of individual public managers and of their public organisations should be directed to all three levels of learning: simple learning (single activities), double learning (improving standard procedures of behaviour) and triple learning (improving the organisations capacity to adapt to the rapidly changing environment in times of heavy turbulence). Only by experiments, by trial and error, by learning by doing and by allowance for making mistakes, both individuals and organisations are able to improve their learning capacities, so teach us modern learning theories. Every modern public organisation, in West and in East, will have to improve its learning capacity in order to survive.

\section{Lesson 9: Ecological analysis}

In line with lesson 8 , more attention should be paid to improving the 'organisational fit' of public organisations. Public organisations do not operate in a vacuum, but in a political, social and economic environment. The extent to which these public organisations fit into their specific environments determines their success in fulfilling their functions and thus their chance for survival in times of turbulence and sudden and radical change.

This lesson implies that the external management of public organisations becomes more and more important as compared to their internal management. Internal management always has been a classical issue in the study and practice of public administration, whereas until recently problems of external management did not receive corresponding attention. Organisational ecology is an important field of attention for public management reform, in particular in relation with institution building (lesson 11 below).

\section{Lesson 10: Organisational culture}

More attention should also be paid to problems of culture, i.e. problems of values, systems of beliefs, ethics, and so on. The culture of organisations determines largely the organisational fit of organisations, as the contingency theory teaches us. Public institutions have an organisational or 'corporate culture'; people within and around these organisations (civil servants, politicians, citizens) are part of this culture.

In particular the political values of citizens and their institutions are an important determinant of the success or failure of public management reform. This is the experience of reform attempts in the Western world, and it certainly plays an important role in Central and Eastern Europe. Public management reform in these countries must be compatible with political and democratic attitudes of the citizens towards their government and public organisations.

Lesson 11: Institution building 
Finally, public management reform in OECD-countries and in Western Europe as well as in countries in Central and Eastern Europe comes down to one central point: the restructuring of existing institutions in the public sector and the building of new ones. 'Institution-building' is the keyword. In West and in East 'reinventing government' is the main issue. In Western Europe this implies the fight against bureaucracy. The experience with many years, and even sometimes decades (the Netherlands since the late nineteen sixties) of public management reform shows us, that more political control of the bureaucracy does not work and even may intensify the bureaucracy problem. The same experience also shows us that the other alternative, radical privatisation, does not work either: privatisation is inefficient because of market failures or results in the substitution of public monopolies by private monopolies as simultaneous competition is absent. From a welfare economic viewpoint, radical privatisation is either impossible or inefficient.

Building and rebuilding institutions may be considered as the heart of public management reform. Institutions do matter. The transition to a market economy shows the importance of institutions, determining the conditions of workable competition (regulation of property and ownership, constitutional guarantees for market behaviour, a national bank and a national currency, and so on). Restructuring the public sector of countries in Central and Eastern Europe also involves institution building. Public institutions operate as the main vehicle for policies; policy structures determine policy processes. Behaviour of individuals and organisations at the micro-level of the politico-economic system determines largely the outcomes at the macro-level of the system. This underlines the relevance of the so-called 'incentive structure': how can we organise individual and organisational behaviour in such a way, that the pursuit of individual self-interests ultimately promotes the public interest of all individuals together as well?

Putting in more competition in the public sector may offer better opportunities to break down the foundations of bureaucratic power. The model of self-management by civil servants may serve as a heuristic device to find competitive solutions. The concept of public entrepreneurship results in ten principles of competitive and market-oriented government. Putting in more competition in the public sector may not only be the better answer to the bureaucracy problem in Western Europe. It also may provide better alternatives for public management reform of the bureaucracy in Central and Eastern Europe. The Western experience with and relative failure of reform attempts consisting of either more political control of the bureaucracy or radical privatisation may teach countries in Central and Eastern Europe teach important lessons. One might doubt seriously whether solutions for public management problems which have been advocated and practised in Western Europe but resulted in relative failure, will work better in Central and Eastern Europe. Probably one may learn better and faster from failure of others than from their success!

\section{Conclusion}

The main conclusions of this chapter can be summarised briefly as follows. Several years, attempts and experiences of public management reform in Western Europe and other OECD-countries gives evidence for relative failure rather than success. Twenty-five years of disappointing outcomes gives rise to fundamental questions such as: why does it not work, what do we do wrong, is it worthwhile to continue public management reform in the same way as has been done in the past? A critical reconsideration of public management reform in the Western world is on the agenda nowadays. 
The various country studies of Western Europe and other OECD-countries in this report give rise to the following overview of problems. The first problem might be, that there is something wrong with the central problem statement. Probably in public management reform the wrong problems have been defined. The second problem is related to this: probably the wrong solutions are attempted in public management reform thus far. Wrong problem statements inevitably lead to the formulations of wrong, incompatible and ineffective solutions. The third problem has to do with many format problems in public management reform programmes.

This experience with public management reform in Western Europe and other OECDcountries is highly relevant for countries in Central and Eastern Europe. Eleven lessons for public management reform in Central and Eastern Europe can be drawn. All these lessons are more or less related to the central idea for a new direction of public management reform in West and in East, i.e., putting in more competition into the public sector. In recent years, the model of 'selfmanagement by civil servants' and the concept of 'public entrepreneurship' have been developed. These new approaches to the organisation of the public sector provide stimulating and new thoughts on public management reform both in Western Europe and in Central and Eastern Europe. They may lead to reformulation of the problem and hence to the development of public management solutions which will work. 


\section{References}

Barry, B.M. and D.W. Rae, 1975, Political Evaluation, in F. Greenstein and N. Polsby (eds.), Handbook of Political Science, Volume 1, Political Science: Scope and Methodology, Reading Mass. 1975, pp. 337-401.

Doel, H. van den, 1979, Democracy and Welfare Economics, Cambridge 1979, (second edition 1993, H. van den Doel and B. van Velthoven).

Mierlo, J.G.A. van, 1985, Improvement of public provision of goods and services, in J.E. Lane (ed.), State and Market, The Politics of the Public and the Private, London-Beverley Hills-New Delhi 1985, pp. 53-69.

Niskanen, W.A., 1971, Bureaucracy and Representative Government, Chicago 1971.

Okun, A.M., 1975, Equality and Efficiency. The Big Trade Off, Washington 1975.

Osborne, D. and T. Gaebler, 1992, Reinventing Government. How the Entrepreneurial Spirit is Transforming the Public Sector, Reading Ma. 1992.

Savas, E.S., 1987, Privatization. The Key to Better Government, Chatham N.J. 1987.

Self, P., 1993, Government by the Market? The Politics of Public Choice, Basingstoke and London 1993.

Vanek, J., 1970, The General Theory of Labor-Managed market Economies, Ithaca/London 1970.

Vanek, J., 1975, Self-management: Economic Liberation of Man, Harmondsworth.

Weber, M., 1922, Wirtschaft und Gesellschaft, Berlin 1922 (fifth edition Tübingen 1972).

Walsh, K., 1995, Public Services and Market Mechanisms. Competition, contracting and the New Public Management, Basingstoke and London.

Williamson, O.E., 1964, Economics of Discretionary Behaviour: Managerial Incentives in a Theory of the Firm, Englewood Cliffs N.J. 1964.

Wilson, W., 1887, The Study of Administration, in Political Science Quarterly, Vol 2, 1887, pp. 197-222. Reprinted in L.C. Gawthrop (ed.), The Administrative Process and Democratic Theory, Boston 1970, pp. 77-85.

Wolf, Ch. jr, 1979, A Theory of Nonmarket Failure: Framework for Implementation Analysis, in The Journal of Law and Economics, 1979, pp. 107-139. Reprinted in F.J. Lyden and E.G. Miller (ed.), Public Budgeting, (fourth edition), Chicago 1982, pp. 97-113.

Wolf, Ch. jr, 1988, Markets or Governments? Choosing between Imperfect Alternatives, Cambridge Ma. 1988. 